tion of vibrations and some rigidity to support the vertebral column should external cardiac compression be necessary. A soft spring mattress (or springs in the trolley axles) makes efficient closed chest cardiac massage difficult. An air mattress effectively prevents transmission of vibration from the trolley to the patient and damps inertial movement. If cardiac massage is necessary the mattress can be deflated within 10 seconds.

Although a hydraulic loading lift on the tail of the ambulance would allow the trolley to be maintained in a horizontal position, such devices are very expensive to fit, and we thought that tilting patients for the few seconds needed to load or unload the trolley would be unlikely to cause anything more than a transient alteration in cardiovascular function.

Using surplus or renovated items of equipment where possible has minimised the capital cost of the mobile intensive care unit. The ventilator, defibrillator, and monitor were purchased specifically for the mobile intensive care unit, as were some parts of the gas-supply system. Engineers in the Nuffield department of anaesthetics modified the trolley, and the ambulance service undertook the alterations and refurbishing of the ambulance. The trolley and its equipment are maintained by technicians of the Nuffield department of anaesthetics, and the ambulance by ambulance service engineers.

As the mobile intensive care unit is manned by those members of the ambulance, medical, and nursing staff who are on call running costs should be low. A senior member of intensive therapy unit medical staff is readily available at all times, and can usually leave the unit temporarily to undertake a transfer. On rare occasions when this is not possible a senior member of the on-call anaesthetic team accompanies the mobile unit. An ambulance crew is required to move the patient whether the mobile intensive care unit is used or not, though the total period of the journey may be longer when it is used. If there is to be a considerable delay before the patient is fit to travel the ambulance crew can resume their normal duties and be called back when required.

We believe that a mobile intensive care unit can make an important contribution towards the safe movement of critically ill patients and that it is a logical extension of a regional intensive care service. With co-operation between clinical, technical, and ambulance staff, such units can be brought into service with low construction and running costs.

\section{References}

1 Waddell G. Movement of critically ill patients within hospital. $\mathrm{Br} \mathrm{Med} \mathcal{F}$ 1975 ;ii:417-9.

2 Waddell G, Scott PDR, Lees NW, Ledingham IMcA. Effects of ambulance transport on critically ill patients. Br Med $\mathcal{F} 1975$;i:386-9.

8 Hothersall AP, Waddell G, Smith HC et al. Mobile intensive care IIsecondary transport. In: Ledingham IMcA, ed. Recent advances in intensive therapy. Edinburgh: Churchill Livingstone, 1977:239-50.

4 Ledingham IMCA, Banks JG. Movement of the critically ill patient. Hosp Update 1980:43-9.

5 Hanning CD, Gilmour DG, Hothersall AP, Aitkenhead AR, Venner RM, Ledingham IMCA. Movement of the critically ill within hospital. Intens Care Med 1978;4:137-43.

B Pichard E, Poisvert M, Hurtaud JP, Ivanoff S, Cara M. Les accelérations et les vibrations dans la pathologie liee au transport sanitaire. Rev Corps Santé 1970;11:611-35.

7 Waddell G, Douglas IHS, Ledingham IMcA. Cardiovascular effects of movement in haemorrhagic shock dogs. Crit Care Med 1974;2:68-72.

\title{
Acute congestive cardiac failure in a hypertensive woman receiving salbutamol for premature labour
}

\author{
M I WHITEHEAD, A M MANDER, K HERTOGS, R M WILLIAMS, $\mathrm{K}$ W PETTINGALE
}

Beta-sympathomimetic agents, such as salbutamol, are widely used to manage premature labour. Pulmonary oedema due to left-sided heart failure has been reported in patients receiving both beta-sympathomimetics and corticosteroids. ${ }^{1}$ Cardiac failure developed in a patient of ours when salbutamol was prescribed in combination with an antihypertensive drug.

\section{Case report}

A 28-year-old previously normotensive West Indian primigravid woman had no clinical evidence of pre-existing cardiac disease. At 27 weeks' gestation her blood pressure rose to $170 / 100$ $\mathrm{mm} \mathrm{Hg}$. During the next four weeks diastolic pressure was main-

\footnotetext{
Departments of Obstetrics and Gynaecology and Medicine, King's College Hospital Medical School, Denmark Hill, London SE5 8RX M I WHITEHEAD, MB, MRCOG, lecturer A M MANDER, MB, MRCOG, senior registrar K HERTOGS, MB, BSC, senior house officer R M WILLIAMS, MA, FRCS, registrar K W PETTINGALE, MD, MRCP, senior lecturer/consultant
}

\begin{abstract}
Antihypertensive treatment combined with a beta-sympathomimetic drug given to delay premature labour may cause congestive cardiac failure.
\end{abstract}

tained below $100 \mathrm{~mm} \mathrm{Hg}$ with alpha-methyldopa, the daily requirement increasing from 1.5 to $2.5 \mathrm{~g}$. Premature labour began at 32 weeks' gestation, and her blood pressure rose to $210 / 140 \mathrm{~mm}$ Hg. Salbutamol, $6 \mu \mathrm{g} / \mathrm{min}$, was infused to suppress uterine activity. Hydrallazine was started with a $10-\mathrm{mg}$ bolus and an infusion was maintained at $27 \mu \mathrm{g} / \mathrm{min}$ for three hours. Six hours after starting salbutamol the patient became breathless with tachypnoea (30 respirations/min). Central venous pressure rose to $8 \mathrm{~cm} \mathrm{H} \mathrm{H}_{2} \mathrm{O}$, and a third heart sound was heard. An electrocardiogram (ECG) showed sinus tachycardia of 130 beats $/ \mathrm{min}$. The patient became anuric: the plasma concentration of potassium was $3.2 \mathrm{mmol} / \mathrm{l}(\mathrm{mEq} / \mathrm{l})$ (normal range 3.7-5.0 mmol/1) and of bicarbonate $11 \mathrm{mmol} / 1$ (mEq/l) (normal range 24-34 mmol/1). The tachypnoea, central venous pressure, and plasma bio- 
chemical abnormalities quickly returned to normal after salbutamol was stopped and $100 \mathrm{mmol}$ of sodium bicarbonate was infused. A $20-\mathrm{g}$ intravenous bolus of mannitol produced a satisfactory diuresis.

Labour started again, and a healthy girl weighing $1500 \mathrm{~g}$ was born vaginally 10 hours later. At delivery the patient again became tachypnoeic (30 respirations/min) with a tachycardia (110 beats $/ \mathrm{min}$ ), and central venous pressure rose to $24 \mathrm{~cm}$ $\mathrm{H}_{2} \mathrm{O}$. Urine output fell in the three hours before delivery to $16 \mathrm{ml} / \mathrm{h}$. Infusing $50 \mathrm{mg}$ intravenous frusemide and $150 \mathrm{mg}$ aminophylline produced a diuresis of $1450 \mathrm{ml}$ in the next three hours. Although the tachypnoea resolved within four hours of delivery, the clinical signs of cardiac failure persisted for 24 hours. The patient required long-term, antihypertensive therapy (labetalol $300 \mathrm{mg}$ and hydrallazine $25 \mathrm{mg}$, both three times a day). ECGs, chest $x$-ray films, and cardiac ultrasound examination performed three days and six months after delivery were normal.

\section{Discussion}

Controlling hypertension during pregnancy with alphamethyldopa has been associated with a pronounced improvement in fetal survival. ${ }^{2}$ Patients who are not pregnant, however, have shown appreciable increases in blood volume after 14 days' treatment. ${ }^{3}$ In one patient the increase was $16 \%$, the body weight increasing by $2.7 \mathrm{~kg}$. Two other patients gained more than $2 \mathrm{~kg}$, and one of these developed congestive cardiac failure at seven days. Premature birth increases the incidence of perinatal mortality. ${ }^{4}$ If beta-sympathomimetic agents such as salbutamol are given intravenously as soon as premature labour starts, delivery may be delayed, ${ }^{5}$ but there may be associated tachycardia and raised plasma insulin, C-peptide, glucose, and lactate concentrations ${ }^{b}$; decreased concentrations of plasma potassium ${ }^{7}$; and ketoacidosis. ${ }^{8}$ Myocardial ischaemia has been reported after salbutamol treatment ${ }^{9}$ and rightsided heart failure ${ }^{1}$ has been reported when salbutamol and corticosteroids are combined. Furthermore, we have been notified by the Committee on Safety of Medicines that a pregnant woman developed cardiac failure after treatment with salbutamol and methyldopa. She died of inhalation of stomach contents, and necropsy showed massive myocardial damage.

We suggest that giving salbutamol to our patient at the onset of premature labour induced a metabolic acidosis and hypokalaemia, which together may have depressed myocardial function ${ }^{1011}$ when the circulating blood volume was high owing to one month's treatment with alpha-methyldopa.

Pregnant patients who receive medication that is likely to increase blood volume should be given a beta-sympathomimetic for premature labour under carefully monitored conditions. Careful attention should be paid to plasma potassium concentrations, the metabolic state, urine output, fluid administration, and above all the clinical markers of early congestive cardiac failure.

\section{References}

1 Elliott HR, Abdulla U, Hayes PJ. Pulmonary oedema associated with ritodrine infusion and betamethasone administration in. premature labour. $\mathrm{Br} \mathrm{Med} \mathcal{F} 1978$;ii :799-800.

${ }^{2}$ Redman CWG, Beilin LJ, Bonnar J. Treatment of hypertension in pregnancy with methyldopa: blood pressure control and side effects. Brf Obstet Gynaecol 1977;84:419-26.

3 Hansen J. Alpha-methyldopa (Aldomet R) in the treatment of hypertension. Acta Med Scand 1968;183:323-7.

4 Anonymous. Drugs in threatened preterm labour. Br Med 7 1979;i:71.

5 de Casparis AW, Thiery M, Sian AYL, et al. Results of double-blind, multicentre study with ritodrine in premature labour. $\mathrm{Br} \mathrm{Med} \mathcal{F} 1971$; iii:144-7.

- Lunell NO, Joelsson I, Larsson A, Persson B. The immediate effect of a $\beta$-adrenergic agonist (salbutamol) on carbohydrate and lipid metabolism during the third trimester of pregnancy. Acta Obstet Gynaecol Scand $1977 ; 56: 475-8$.

7 Thomas DJB, Dove AF, Alberti KGMM. Metabolic effects of salbutamol infusion during premature labour. Br $\mathcal{F}$ Obstet Gynaecol 1977;84:497-9.

${ }^{8}$ Leopold D, McEvoy A. Salbutamol-induced ketoacidosis. $\mathrm{Br} \mathrm{Med} \mathcal{F}$ 1977;ii:1152-3.

- Whitehead MI, Mander AM, Hertogs K, Rothman MT. Myocardial ischaemia after withdrawal of salbutamol for preterm labour. Lancet 1979 ;ii:904

${ }^{10}$ Darby TD, Aldinger EE, Gadsden RH, Thrower WB. Effects of metabolic acidosis on ventricular isometric systolic tension and the response to epinephrine and levarteronol. Circ Res $1960 ; 8: 1242-53$.

11 Wenger NK. Myocardial involvement in systemic disease. In : Hurst JW, Logue RB, Schlant RC, Wenger NK, eds. The heart, arteries and veins. Tokyo: McGraw-Hill Kogakusha, 1974:1360.

(Accepted 11 fanuary 1980)

\section{MATERIA NON MEDICA}

\section{Australian painters}

Australia is a country where water can get so short that almost everybody seems to put a metal roof on their house to facilitate rain collection-and even the tiniest of smallholdings has its own dam (pond) near by. But occasionally the heavens open. A useful haven in wet weather for travellers everywhere is a local art exhibition, and the Gallery of New South Wales in Sydney houses a splendid collection and good shelter in a cloudburst. I left the Turners and Rembrandts to the locals and was overwhelmed by the work of nineteenth- and twentieth-century Australian painters. The heat and sometimes the hopelessness of life in the bush bursts out of Frederick McCubbin's "On the Wallaby Track" in a way that underlines the inadequacy of the written word. "Bailing up one of Her Majesty's mail coaches" comes to life with Tom Roberts's brush, ant the hazards and charm of late nineteenth-century travel in NSW are captured for ever for us.

Perhaps the most fascinating of all Australian painters is Rupert Bunny. Elegant conversation pieces between nineteenth-century Australian ladies and their servants, illuminated by the harsh white light of New South Wales, compare favourably with our European masters of the art of capturing the rich at play and the poor at work. In other canvases he could be Matisse or perhaps even Picasso changing his style with a rare facility and apparent ease-never the plagiarist, always his own man. Some of the pictures in Sydney's rather forbidding "National Gallery" type of building defy logic and reasoning. How can a composition as banal as Elioth Gruner's "Spring Frost" escape the chocolate box ? W C Piguenit's "The Flood in the Darling" should theoretically be a disaster too, and indeed is so in the postcard reproductions of it. But this masterpiece of 1895 dominates a wall in the gallery the size of a tennis court. The nineteenth-century painters of Australia are liable to persuade you to trade a dictionary of words for a brushful of paint and, if you aren't terribly careful, make you believe in magic as well.-ERIC TRIMMER (general practitioner, London).

\section{Bellringing}

There are records of doctors as bellringers-of tower bells and hand bells-going back a hundred years. But it was not until 1955 that they got together to form a guild. This is now flourishing and there are great plans to celebrate the 25th anniversary on the date of this issue. Originally comprising only doctors, the guild membership now includes dentists, nurses, and many of the newer health disciplines, but doctors still tend to predominate numerically. The English art of change-ringing started in seventeenth-century London and East Anglia, though it has now spread to the rest of the UK and to the Commonwealth. As Dorothy Sayers said in The Nine Tailors, the art is peculiarly satisfying both to the musician and mathematician. It is constantly developing new variations and its theory has become, inevitably, computerised. But, from the tender age of 11 , anyone can get a lot of pleasure-and render service to their parish churchwithout bothering overmuch about the complexities. Moreover, the social side is well developed; not for nothing is the pub adjoining the church often called "The Bell" or "The Ring of Bells." Harmony prevails both during and after the exercise. So, if your $B M \mathcal{F}$ has reached you think of the campanological health care team celebrating happily. And if the thought intrigues you, learn the skill, and join us. After all, few churches have telephones-you are out of this world. -D L GULLICK (Welwyn, Herts). 